\title{
Effect of bio-fertilizers application on microbial diversity and physiological profiling of microorganisms in arable soil
}

\author{
Soňa Javoreková a,*, Jana Maková a, Juraj Medo a, Silvia Kovácsová a, \\ Ivana Charousová a Ján Horák b \\ a Department of Microbiology, Slovak University of Agriculture in Nitra, Nitra, Slovakia \\ b Department of Biometeorology and Hydrology, Slovak University of Agriculture in Nitra, Nitra, Slovakia
}

\begin{abstract}
In laboratory assay, the diversity of bacteria and microscopic fungi and the community-level physiological profiling (CLPP) of microorganisms were observed after the addition of bio-sludge (40 t.ha-1) from a biogas station and addition of bio-fertlizers - AZOTER $\left(10 \mathrm{dm}^{-3} \cdot \mathrm{ha}^{-1}\right)$ to the arable soil with PCR-DGGE and BIOLOG ${ }^{\circledR}$ method (Eco Plates). The differences were recorded in the microbial diversity (bacteria and microscopic fungi) among variants according to the Shannon index. The differences in community of microscopic fungi were markedly higher among the soil samples with the additions of both bio-fertilizers compared to control soil samples. The occurrence of individual OTUs (operational taxonomic units) bacteria and microscopic fungi were different after 105 days of incubation from the status after the $1^{\text {st }}$ day of incubation. The community metabolic diversity (CMD) was influenced by the incubation time (105 days) as well, but not by application of bio-fertilizers. We observed a significant decrease (LSD test, $\mathrm{P}<0.05$ ) in community metabolic diversity (CMD) and average metabolic response (AMR) of microorganisms in samples collected on the $105^{\text {th }}$ day of the experiment compared to samples collected on the $1^{\text {st }}$ day of the experiment in all tested samples.

Accepted : 22.11.2014
\end{abstract}

Keywords: bio-fertilizers, microbial diversity, microbial physiological profiling, arable soil

(C) 2014 Federation of Eurasian Soil Science Societies. All rights reserved

\section{Introduction}

Bio-fertlizers has been identified as an alternative to chemical fertilzers to increase soil fertility and crop production in sustainable farming. Bio-fertilizer as a substance which contains living microorganisms which, when applied to seed, plant surfaces or soil, colonizes the rhizosphere or the interior of the plant and promotes growth by increasing the supply or availability of primary nutrients to the host plant (Vessey, 2003). Bio-fertlizers have emerged as an important component of the integrated nutrient supply system and hold a great promise to improve crop yields through environmentally better nutrient supplies (Wu et al., 2005). A bio-fertlizers can to contain usually Azotobacter chroococcum (Gutiérrez-Rojas et al., 2011) as a Nfixer, Bacillus megaterium as a P solubilizer, Bacillus mucilaginous as a K solubilizer and Glomus mosseae and Glomus intraradices as a arbuscular mycorrhizal fungi. The term biosludge or sewage sludge represents the insoluble residue produced during wastewater treatment and subsequent sludge stabilization procedures, such as aerobic or anaerobic digestion (Arthurson, 2008). Application of bio-fertlizers and biosludge to arable soil influensed physical and chemical properties of soil but as well structure and funtion of soil microbial community (Preston-Mafham et al., 2002; Marschner et al., 2003; Chu et al., 2007; Gu et al., 2009; Cercioglu et al., 2014).

\footnotetext{
${ }^{*}$ Corresponding author.

Department of Microbiology, Slovak University of Agriculture in Nitra, tr.A.Hlinku 2, 94976 Nitra, Slovakia

Tel.: +421376414431

E-mail address: sona.javorekova@uniag.sk

ISSN: 2147-4249
} 
The changes of microbial carbon, microbial diversity (PCR DGGE) and the community-level physiological profiling (CLPP) of microorganisms were observed after the addition of bio-sludge from a biogas station, addition of bio-fertlizers Azoter and both of organic manure to the sandy arable soil in laboratory conditions. Our working hypothesis is that arable soil amendment with both of bio-fertlizers should be to improve selected microbial charactersitic and consecutively soil fertility sandy soil in comparison with application organic manure separately.

\section{Material and Methods}

\section{Collection and characteristic of soil, biosludge and biofertilizer}

The arable soil used for this pot experiment was collected randomly in Štefanov $\left(48^{\circ} 40^{\prime} 54^{\prime \prime}\right.$ W; $17^{\circ} 12^{\prime} 17^{\prime \prime}$ S), district Senica in region Záhorie (western Slovakia bordered by the Little Carpathians in the east and the Morava River in the west) in a spring period. The main soil characteristics in the $0.00-0.20 \mathrm{~m}$ surface layer were established before sowing of crops. The soil type was sandy regosols (55\% sand) with the next basic properties of the the soil: $5.27 \mathrm{pH}_{\mathrm{H} 2 \mathrm{O}}$ and $4.26 \mathrm{pH}_{\mathrm{KCl}}, 0.42 \%$ organic mater content $\left(\mathrm{C}_{\mathrm{org}}\right), 0.724 \%$ content of humus, microbial carbon $120,30 \mu \mathrm{g} \mathrm{C}_{\text {mic }} \mathrm{g}^{-1}, 2,86 \% \mathrm{C}_{\text {mic }} / \mathrm{C}_{\text {org }}, 0.037 \%$ total $\mathrm{N}\left(\mathrm{N}_{\mathrm{t}}\right), 11.35$ ratio C/N.

Soil in laboratory experiment was amendment by mixed with two organic manure: biosludge rate of 40 tons ha $^{-1}$ and biofertilizer rate of $10 \mathrm{dm}^{-3} \mathrm{ha}^{-1}$. Biosludge was collected from biogas station at the School Agricultural Enterprise In Kolíňany of the Slovak Agricultural University in Nitra. Biosludge was produced by anaerobic fermentation from agricultural wastes $(20 \%$ beef dung and $80 \%$ piggish dung) in mesophilic conditions $\left(35-40{ }^{\circ} \mathrm{C}\right)$. Biosludge after fermentation was 20 days holding-up in fermentor and six months stored in storage tanks. Content of solid in biosludge in the end of storage was $3.83 \%, \mathrm{C}_{\text {ox }} 30.71 \%, \mathrm{~N}_{\text {tot }} 2.47$ $\%$, ratio $\mathrm{C} / \mathrm{N} 12.42$ and actual $\mathrm{pH}_{\mathrm{H} 20}$ 7.76. Content of heavy metals was lower than tolerable limit values of $\mathrm{Pb}\left(15.293 \mathrm{mg} \mathrm{kg}^{-1}\right), \mathrm{Cd}\left(0.224 \mathrm{mg} \mathrm{kg}^{-1}\right), \mathrm{Hg}\left(0.125 \mathrm{mg} \mathrm{kg}^{-1}\right)$ and As $\left(0.565 \mathrm{mg} \mathrm{kg}^{-1}\right)$ according to Statutebook in Slovakia (No. 577/2005). Biofertilizer Azoter was produced by company Biofactory Petrova Ves in Slovakia. This product consist according to producer bacteria as Azotobacter chroococcum $6 \times 10^{9} \mathrm{CFU} \mathrm{ml}^{-1}$, Azospirillum brasilience $5 \times 10^{9} \mathrm{CFU} \mathrm{ml}^{-1}$ and Bacillus megaterium $1.2 \times 10^{9} \mathrm{CFU} \mathrm{ml}^{-1}$. Production medium contained molasses (carbon source), mineral substance $\left(\mathrm{KH}_{2} \mathrm{PO}_{4}, \mathrm{MgSO}_{4}, \mathrm{CaCO}_{3}, \mathrm{NaCl}, \mathrm{CaCl}_{2}\right)$, cellulose and micronutrient. Biofertilizer Azoter was grey, compact liquid with typical molasses aroma. According to producer after application in soil Azoter amendment soil parametres as release of nitrogen, phosphorus, potassium and production plant hormones.

\section{Experiment design}

Four treatments (T1, T2, T3, T4) were tested in the laboratory assay. The treatment details are given in Table 1. Soil ( $350 \mathrm{~g}$ ) was filled in plastic box $15^{*} 10^{*} 6 \mathrm{~cm}$ in aprox. $2 \mathrm{~cm}$ layer.. Each variant was set up in 15 boxes, which were stored in aerobic condition in dark thermostat $\left(28^{\circ} \mathrm{C}\right)$. Humidity of soil was set to $50 \%$ of full water holding capacity. They were controlled and re-moistened to $50 \%$ water holding capacity in 3 day period. Three boxes (replicates) for each variant were analyzed after 1, 15, 30, 64 and 105 days of experiment in the all treatments.

Table 1. Experimental design for soil amendments with organic manure

\begin{tabular}{ll} 
Treatment details & \\
\hline T1 (control) & Experimental soil $(\mathrm{S})$ \\
$\mathrm{T} 2$ & Experimental soil + Azoter $(\mathrm{S}+\mathrm{A})$ \\
$\mathrm{T} 3$ & Experimental soil + biosludge $(\mathrm{S}+\mathrm{B})$ \\
$\mathrm{T} 4$ & Experimental soil + Azoter + biosludge $(\mathrm{S}+\mathrm{A}+\mathrm{B})$ \\
\hline
\end{tabular}

\section{Chemical analysis}

The microbial biomass $\mathrm{C}_{\text {mic }}$ was determined the all treatments in triplicate after 1, 15, 30, 64 and 105 days of soil samples incubation by fumigation-extraction as describred by Vance et al. (1987). $C_{\text {mic }}$ was calculated by the equation: $C_{m i c}=C_{\text {ext }} \times 2.65$, where $C_{\text {ext }}$ is the difference between the $C$ extracted from the fumigated and non-fumigated samples. Organic carbon $\left(\mathrm{C}_{\mathrm{ox}}\right)$ was determined the all treatments in triplicate after 1,15 , 30,64 and 105 days according to the standard Tyurin titrimetric method using $\mathrm{K}_{2} \mathrm{Cr}_{2} \mathrm{O}_{7}$ oxidation.

\section{DNA extraction and PCR DGGE}

Total soil DNA was extracted from each sample $(0.25 \mathrm{~g})$ using PowerSoil DNA Kit (MoBio Laboratories). Concentration and quality of extracted DNA was checked spectrophotochemically (Ultrospec 1000, 
Pharmacia Biotech) and on the 1\% agarose gel, too. DNA was the next step diluted to the equal concentration with the deinoized water for use on determination bacterial and fungal community in PCR DGGE.

Bacterial 16S rDNA was amplified by using the primer F984GC and 1401R (Brons and Van Elsas, 2008). The total reaction volume was $50 \mu \mathrm{l}$ and containing $5 \mu \mathrm{l}$ of template DNA; $1 \times$ PCR DreamTaqTM Green Buffer; 0.2 mM dNTP; $3.5 \mathrm{mM} \mathrm{MgCl}_{2} ; 2 \%$ dimetyl sulfoxid; $10 \mu \mathrm{g} . \mathrm{ml}^{-1} \mathrm{BSA} ; 0.4 \mu \mathrm{M}$ of each primer (F984GC a 1401R) and $30 \mathrm{U} / \mathrm{ml}$ DreamTaqTM polymerázy (Fermentas). PCR reaction conditions were $95{ }^{\circ} \mathrm{C}$ for $4 \mathrm{~min} ; 10$ (touchdown) cycles with declining hybridization temperature for $0.5^{\circ} \mathrm{C}$ on cycles, with following profile: 1 $\min$ at $94^{\circ} \mathrm{C} ; 1 \mathrm{~min}$ at $60^{\circ} \mathrm{C} ; 2 \mathrm{~min}$ at $72{ }^{\circ} \mathrm{C}$. Bacterial DNA was amplified in 25 cycles of $1 \mathrm{~min}$ at $94{ }^{\circ} \mathrm{C} ; 1$ min at $55^{\circ} \mathrm{C} ; 2$ min at $72{ }^{\circ} \mathrm{C} ; 30 \mathrm{~min}$ at $72^{\circ} \mathrm{C}$ in TPersonal thermocycler (Biometra).

DNA of eukaryotic microorganisms (18S rDNA) was amplified using the primer pair FF390 and FR1GC (Vainio and Hantula, 2000). The total reaction volume was $50 \mu \mathrm{l}$ and containing $5 \mu \mathrm{l}$ of template DNA; $1 \times$ PCR DreamTaqTM Green Buffer with KCl; $0.2 \mathrm{mM}$ dNTP; $1.5 \mathrm{mM} \mathrm{MgCl} 2 ; 0.5 \mu \mathrm{M}$ of each primer (FF390 a FR1GC) and $30 \mathrm{U} / \mathrm{ml}$ DreamTaqTM polymerázy (Fermentas). PCR reaction conditions were $95^{\circ} \mathrm{C}$ for 8 min; $30 \mathrm{x}\left(30 \mathrm{~s}\right.$ at $95^{\circ} \mathrm{C} ; 45 \mathrm{~s}$ at $60{ }^{\circ} \mathrm{C} ; 2 \mathrm{~min}$ at $\left.72{ }^{\circ} \mathrm{C}\right) ; 10 \mathrm{~min}$ at $72{ }^{\circ} \mathrm{C}$. Succcessful amplification was verified by electrophoresis in $1 \%(\mathrm{w} / \mathrm{v})$ agarose gels with SYBR green I nucleic acid staining.

DGGE analysis was performed in Ingeny PhorU2 apparatus (Ingeny). For bacterial (433 bp) PCR product we used $6 \%$ concentration of acrylamide gel (acrylamide: $\mathrm{N}, \mathrm{N}^{\prime}$-methylenebisacrylamide, w/w, 37.5:1) with 45$65 \%$ gradient (Garbeva et al., 2004). For product of microscopic fungi (390bp) we used 45-60\% gradientand $7.5 \%$ concentration of acrylamide gel (Vainio a Hantula, 2000). Running conditions were for bacterial DNA $60{ }^{\circ} \mathrm{C}, 110 \mathrm{~V}, 16$ hours and fungal DNA $58{ }^{\circ} \mathrm{C}, 90 \mathrm{~V}, 17$ hours in $1 \mathrm{x}$ TAE buffer $(40 \mathrm{mM}$ Trisacetate, $1 \mathrm{mM}$ EDTA, pH 7.5). Gels were stained by SYBR Green I farbivom (1:10 000, Fermentas) for 1 hour, subsequently gels were photographed by Gel Logic 212 PRO Imaging System (Carestream Health, Inc., USA) and quantity of bands was assessed by Carestream software.

\section{Community level physiological profiles (CLPPs)}

CLPPs were assessed using the 96-well BIOLOG ${ }^{\circledR}$ Eco MicroPlates $^{\mathrm{TM}}$, (Biolog Inc., USA), comprising 31 sole carbon substrates ( 8 carbohydrates, 8 carboxylic acids, 4 polymers, 6 amino acids, 2 amines and 3 miscellaneous substrates), three times replicated on each microplate. Five grams of field-moist soil was suspended in $45 \mathrm{ml} 0.87 \% \mathrm{NaCl}$ solution, shaken for $30 \mathrm{~min}(90 \mathrm{rpm})$ and left to settle for a further $30 \mathrm{~min}$, after which a 100-fold serial dilution was made and $100 \mu \mathrm{l}$ inoculated directly onto EcoPlates and dark aerobic incubated at $30 \pm 1^{\circ} \mathrm{C}$. Plates were read 24 hourly at $590 \mathrm{~nm}$ for 8 days $(192 \mathrm{~h})$ spectrophotometrically on the Microplate Reader (ELx808 ${ }^{\mathrm{TM}}$; BioTek). The optical density (OD) for each well was calculated as control well OD minus substrate well OD at $24 \mathrm{~h}$ (Garland and Mills, 1991). Microbial activity was then calculated as average well colour development (AWCD) (Garland and Mills, 1991) at $24 \mathrm{~h}$. Due to detection limitations, wells with an average OD $\leq 0.2$ were set to zero. According to Laboratory for microbial ecology (2004) we are calculeted two parameters: average metabolic response (AMR) and community metabolic diversity (CMD).

\section{Statistical analysis}

Principal component analysis (PCA) of DGGE data was done in STATISTICA 7 (Statsoft) using quantity of bands respectively absorbance of wells for each sample. Band (Operational Taxonomic Unit- OUT) was counted as present only if it appeared in 2 of 3 replicates. PCA graph was visualized by Microsoft excel. For each sample analyzed by DGGE, Shannon's index of diversity based on natural logarithm was calculated. For summary analysis of CLPP Average metabolic response (AMR) was calculated according to Gomez et al. (2004): $A M R=\Sigma O D_{(1-i)} / 31$. Further, AMRs were compared using ANOVA. Analysis of variance performed in Statistica 7 was used also for microbial carbon and microbial quotient $\mathrm{C}_{\mathrm{mic}} / \mathrm{C}_{\text {org. }}$.

\section{Results and Discussion}

Organic and inorganic fertlizer amendments are used primarily to increase nutrient availability to plants, but the can also affect structure and function of the soil microbial community (Marschner et al., 2003). Increase values of microbial biomass (Table 2), especially on the early 30 days of the laboratory experiment confirmed, that applied organic fertilizers were a suitable source for the growth and reproduction of the soil microorganisms. The soil under test had a very short supply of the stable organic carbon, because we recorded marked increase of carbon of microbial biomass $\left(\mathrm{C}_{\mathrm{mic}}\right)$. Addition of the all tested organic fertilizers (Azoter, biosludge and mixture of both) to the soil caused statistically significant increase in values of microbial biomass in comparison with soil without fertilizers. Microbial biomass increased the highest 
about $230 \%$ (in the first day) and $329 \%$ (in the last day) after trial establishment in treatment amended mixture of both fertilizers.

According to the fact, that organic matter content in tested soil samples was very small $(0.42 \%)$, we have been interested in proportion of microbial biomass in this substrate. Values of microbial quotient are in the range of 1-5 \% of soil organic matter in agricultural soils. This quotient was the higher in the amended soil we analysed. It was $2.86 \%$ at the beginning of our experiment (day 0). After the first 24 hours of treated soil samples incubation we found increase of value from $4.94 \%$ (T2) to $6.77 \%$ (T4), but also a high proportion of carbon (3.46\%) of microbial biomass in control (T1). After $30^{\text {th }}$ day of the experiment the next incubation of soil samples and by decrease of microbial biomass, we found out a decrease of microbial quotient. The lowest values of microbial quotient were determined on $105^{\text {th }}$ day in amended soil with fertilizers, but the higher than on the control treatment. Statistical significant differences $C_{\text {mic }} / C_{o x}$ we observed the all treatments only the 1 st day of experiment.

The next we observed which part from microorganisms (bacterial or fungal) caused on the increase of microbial carbon in soil amended with fertilizers. Some authors (Crecchio et al., 2001; Marschner et al., 2001) have reported that at short-term experiments without regular application of fertilizers were not determine striking long-term changes of bacterial community. But in case of long-term fertilization of agricultural soil by organic manure was determined increase of diversity and composition of microbial community (Franzluebbers et al., 2004). According to Wu et al. (2005) bio-fertlizers are products containing arbuscular mycorhizal fungi, $\mathrm{N}$-fixers (Azotobacter chroococcum), P-solubilizers (Bacillus megaterium) and $\mathrm{K}$ solubilizers (Bacillus mucilaginous), which improve chemical properties of the soil, for example content of organic matter and content of a total carbon.

Table 2. Influence of application biofertilizer Azoter and biosludge to the arable soil on the microbial carbon ( $\mu \mathrm{g} \mathrm{C.g-1}$ pôdy) and microbial $\mathrm{Cmic}_{\mathrm{m}} / \mathrm{Corg}_{\mathrm{g}}(\%)$ during 105 days laboratory incubation

\begin{tabular}{llccccc}
\hline Parameter & Treatment & \multicolumn{5}{c}{ Day of observation } \\
\cline { 3 - 6 } & & 1. & 15. & 30. & 64. & 105. \\
\hline C mic & T1 & $123.37 \pm 1.25^{\mathrm{a}}$ & $124.17 \pm 17.93^{\mathrm{a}}$ & $141,29 \pm 9.59^{\mathrm{a}}$ & $106.01 \pm 5.52^{\mathrm{a}}$ & $49.88 \pm 1.29^{\mathrm{a}}$ \\
& T2 & $186.42 \pm 3.49^{\mathrm{b}}$ & $185.43 \pm 7.10^{\mathrm{b}}$ & $212.34 \pm 20.82^{\mathrm{b}}$ & $120.60 \pm 17.07^{\mathrm{ab}}$ & $62.30 \pm 6.04^{\mathrm{a}}$ \\
& T3 & $250.27 \pm 10.31^{\mathrm{c}}$ & $248.89 \pm 25.19^{\mathrm{c}}$ & $283.37 \pm 13.12^{\mathrm{c}}$ & $147.28 \pm 11.47 \mathrm{~b}$ & $98.04 \pm 8.36^{\mathrm{b}}$ \\
& T4 & $290.76 \pm 9.52^{\mathrm{d}}$ & $267.86 \pm 17.24^{\mathrm{c}}$ & $288.69 \pm 5.74^{\mathrm{c}}$ & $189.75 \pm 4.99^{\mathrm{c}}$ & $164.37 \pm 18.72^{\mathrm{c}}$ \\
\hline C $_{\text {mic }} /$ Corg & T1 & $3.46 \pm 0.32^{\mathrm{a}}$ & $3.48 \pm 0.23^{\mathrm{a}}$ & $3.45 \pm 0.27^{\mathrm{a}}$ & $3.39 \pm 1.00^{\mathrm{a}}$ & $1.85 \pm 0.45^{\mathrm{a}}$ \\
& T2 & $4.94 \pm 0.57^{\mathrm{b}}$ & $4.20 \pm 0.32^{\mathrm{b}}$ & $4.82 \pm 0.50^{\mathrm{b}}$ & $3.35 \pm 0.86^{\mathrm{a}}$ & $2.04 \pm 0.31^{\mathrm{b}}$ \\
& T3 & $6.20 \pm 0.08^{\mathrm{c}}$ & $5.23 \pm 0.50^{\mathrm{bc}}$ & $5.42 \pm 0.36^{\mathrm{bc}}$ & $3.77 \pm 0.05^{\mathrm{a}}$ & $3.04 \pm 0.33^{\mathrm{b}}$ \\
& T4 & $6.77 \pm 0.54^{\mathrm{c}}$ & $5.61 \pm 0.66^{\mathrm{c}}$ & $5.78 \pm 0.15^{\mathrm{c}}$ & $4.89 \pm 0.80^{\mathrm{a}}$ & $4.21 \pm 0.43^{\mathrm{c}}$ \\
\hline
\end{tabular}

(Means followed by the same letter (s) within each column are not significantly different at $\mathrm{P} \leq 0.05$ )

\section{PCR DGGE}

The results of PCR-DGGE method show that the addition of bio-fertilizer influenced the structure of the soil microbial community. We identified 44 different operational taxonomic units (OTU) after bacterial DNA analysis. The increase of OTU was found in variants with the addition of Azoter and Azoter with biosludge after 105 days compared to the $1^{\text {st }}$ day of incubation (Table 3). The results from correlation graph of principal components analysis (PCA) confirmed differences in composition of community at the beginning and at the end of the experiment as well as differences between the variants where biosludge was added (T3 and T4), compared with the soil and soil treated with Azoter (Figure 1).

We recorded more significant effect of added biofertilizers (Figure 2) after 105 days in case of community of fungi, especially in soil treated with biosludge and with biosludge with Azoter. As in the case of bacteria as well in the case of fungi we have seen an increase of OTU in variants with biosludge. It was confirmed that the addition of biosludge provide several potential benefits to microorganisms. Except of increasing of the quantity and quality of the organic material provides also macro-and micro-elements and improves the physical properties of soil. Positive impact of application of biosludge to the amount of microscopic fungi species mentione also Anderson et al. (2008). This positive impact is probably only short-lived and after long-term application does not occur significant changes in both communities (Odlare et al., 2011). Crecchio et al., (2004); Guanghua et al., (2008); Cherif et al., (2009) did not find significant changes in the bacterial community after application of manure, compost and fertilizers, Ge et al. (2008) confirm significant changes in the community of microorganisms after fertilization with organic waste, including biosludge. 
A)

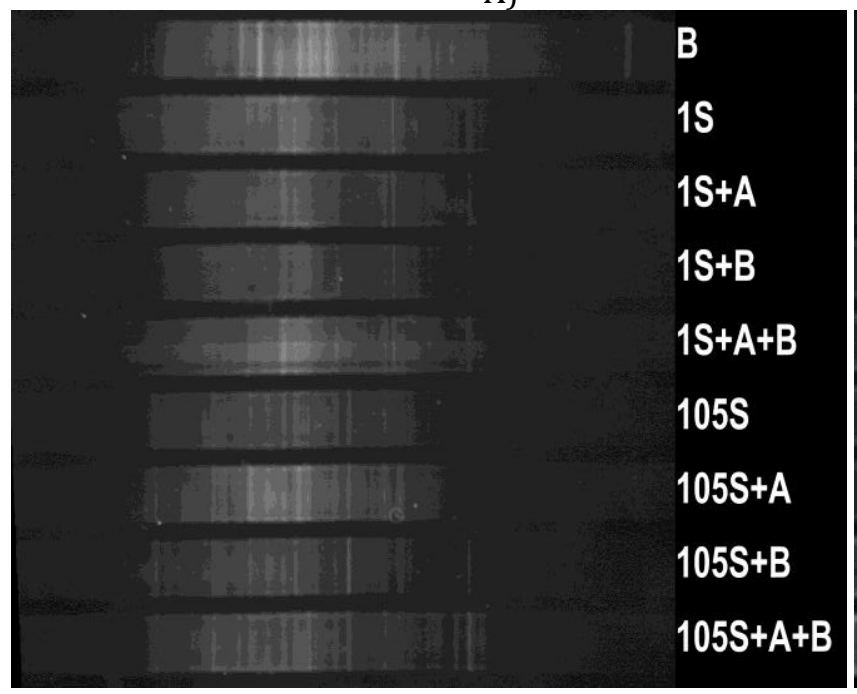

B)

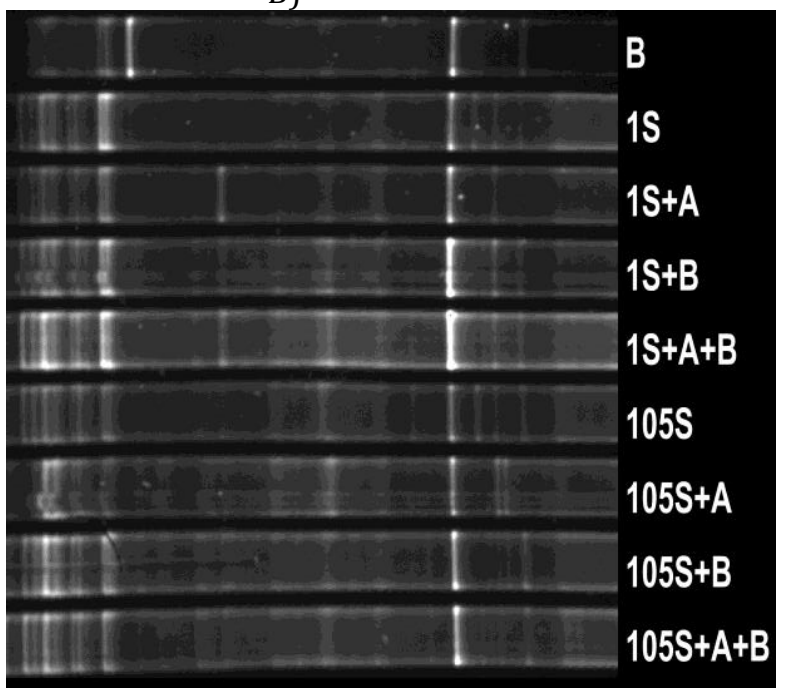

Figure 1. Denaturing gradient gel electrophoresis banding patterns of $16 \mathrm{~S}$ rDNA fragments (A) and 18S rDNA (B) fragments for the biosludge and treatments with application biofertilizer Azoter and biosludge to the arable soil in the $1^{\text {st }}$ and $105^{\text {th }}$ day of experiment

Table 3. Number of OTU according to results from PCR DGGE bacterial and fungal community for the beginning ( $1^{\text {st }}$ day) and the ending $\left(105^{\text {th }}\right.$ day) of the experiment

\begin{tabular}{|c|c|c|c|c|c|}
\hline \multicolumn{3}{|c|}{ Bacteria } & \multicolumn{3}{|c|}{ Microscopic fungi } \\
\hline Treatment & OTU & Shannon index & Treatment & OTU & Shannon index \\
\hline \multicolumn{6}{|c|}{$1^{\text {st }} / 105^{\text {th }}$ day } \\
\hline B & 26 & 2.89 & B & 13 & 1.94 \\
\hline $\mathrm{T} 1$ & $26 / 28$ & $2.98 / 3.02$ & $\mathrm{~T} 1$ & $19 / 21$ & $2.41 / 2.43$ \\
\hline $\mathrm{T} 2$ & $23 / 29$ & $2.87 / 2.98$ & $\mathrm{~T} 2$ & $20 / 25$ & $2.55 / 2.56$ \\
\hline T3 & $26 / 30$ & $2.72 / 2.99$ & T3 & $25 / 27$ & $2.29 / 2.69$ \\
\hline $\mathrm{T} 4$ & $29 / 31$ & $2.98 / 3.07$ & $\mathrm{~T} 4$ & $25 / 28$ & $2.48 / 2.76$ \\
\hline
\end{tabular}

A)

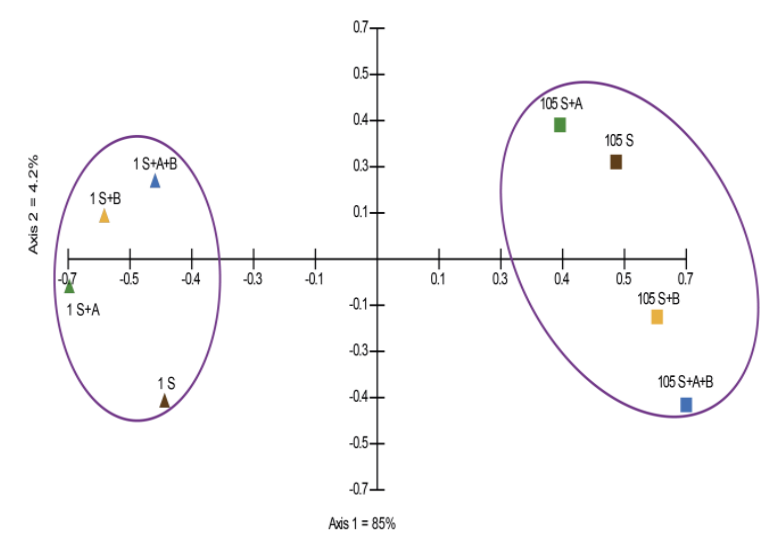

B)

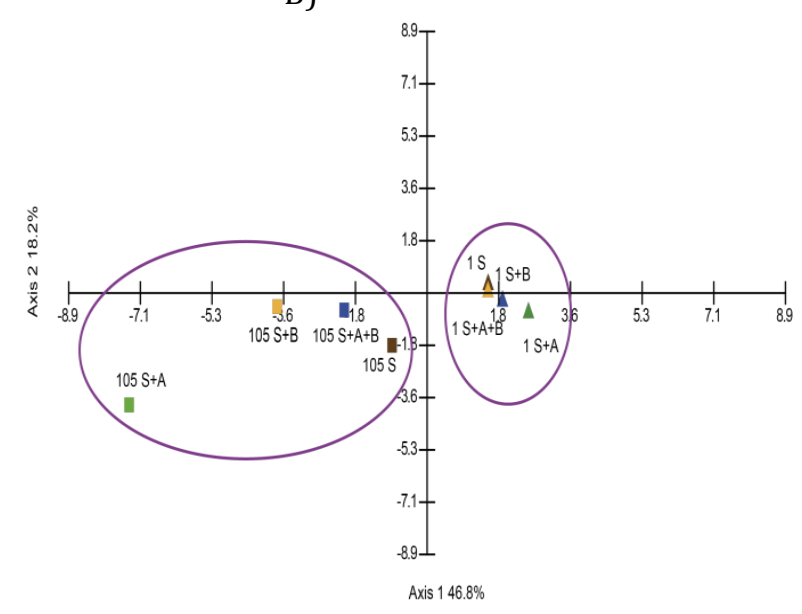

Figure 2. Principal component analysis of PCR DGGE bacterial community (A) and fungal community (B) after application biofertilizer Azoter, biosludge and both to the arable soil in the $1^{\text {st }}$ and $105^{\text {th }}$ day of experiment 


\section{Community-level physiological profiling (CLPP)}

The physiological characterization of microbial community in soil with applied bio-fertilizers was monitored for 192 hours on EcoPlates. The present microcenosis confirmed the different ability of microorganisms to metabolize 31 offered substrates (Table 4).

Compared to the control treatment, we found that the addition only of the Azoter in the first day of experiment supported the decomposition of substrates to almost $94 \%$. From the available substrates was most frequently used $\beta$-methyl-D-glucoside, L-erythritol, $\alpha$-cyclodextrin, $\alpha$-ketobutyric acid, $\alpha$-D-lactose and D, L- $\alpha$-glycerophosphate. We recorded lower percentage of the used substrates $(87 \%$ and $81 \%)$ in the case of application of biosludge and the also the two bio-fertilizer into the soil. This finding is in accordance with the results of Guanghua et al. (2008) who in study aimed to observe the effect of fertilization on the structure and function of microorganisms community also indicate that, in the case of application of organic fertilizers, the ability of microorganisms to use available sources of carbon during incubation on Biolog ${ }^{\circledR}$ Eco plates, compared with the soil, markedly increased. But this catabolic ability of microorganisms decreased gradually with the decomposition of available substrates and in the last day of incubation decreased most notably in soil with the addition of Azoter up to 10\%. We observed the highest degradation of substrates (29 $\%$ ) in variant with soil (T1) and in the variant of Azoter the lowest (9.7\%).

Table 4. Utilization of organic substrates with soil microbial community after application bio-fertilizers for the beginning ( $1^{\text {st }}$ day $)$ and the ending $\left(105^{\text {th }}\right.$ day $)$ of the experiment

\begin{tabular}{|c|c|c|c|c|}
\hline \multirow[t]{2}{*}{ Carbon sources } & \multicolumn{4}{|c|}{ Treatment } \\
\hline & $\mathrm{T} 1$ & $\mathrm{~T} 2$ & T3 & $\mathrm{T} 4$ \\
\hline$\beta$-metyl-D-glukoside & $-1-$ & $+/-$ & $-1-$ & $-1-$ \\
\hline D-galactonic acid $\gamma$-laktone & $+/-$ & $+/-$ & $+/-$ & $+/-$ \\
\hline L-arginine & $+/-$ & $+/-$ & $+/-$ & $+/+$ \\
\hline Pyruvic acid methyl ester & $+/+$ & $+/+$ & $+/+$ & $+/+$ \\
\hline D-xylose & $+/+$ & $+/+$ & $+/+$ & $+/+$ \\
\hline D-galacturonic acid & $+/+$ & $+/-$ & $+/-$ & $+/+$ \\
\hline L-asparagine & $+/+$ & $+/-$ & $+/-$ & $+/+$ \\
\hline Tween 40 & $+/+$ & $+/-$ & $+/-$ & $+/-$ \\
\hline L-erythritol & $-/-$ & $+/-$ & $+/-$ & $+/-$ \\
\hline 2-hydroxy benzoic acid & $+/-$ & $-/-$ & $+/-$ & $-/-$ \\
\hline L-phenylalanine & $+/-$ & $+/-$ & $+/-$ & $+/-$ \\
\hline Tween 80 & $+/+$ & $+/+$ & $+/+$ & $+/+$ \\
\hline D-mannitol & $+/-$ & $+/-$ & $+/-$ & $+/+$ \\
\hline 4-hydroxy benzoic acid & $+/-$ & $+/-$ & $+/+$ & $+/-$ \\
\hline L-serine & $+/-$ & $+/-$ & $+/-$ & $+/-$ \\
\hline$\alpha$-cyklodextrin & $-/-$ & $+/-$ & $+/-$ & $-/-$ \\
\hline $\mathrm{N}$-acetyl-D-glucosamine & $+/+$ & $+/-$ & $+/+$ & $+/-$ \\
\hline$\gamma$-hydroxybutyric acid & $+/-$ & $+/-$ & $+/-$ & $+/-$ \\
\hline L-threonine & $+/-$ & $+/-$ & $+/-$ & $+/-$ \\
\hline Glycogen & $-1-$ & $+/-$ & $-/-$ & $-/-$ \\
\hline D-glucosaminic acid & $+/-$ & $+/-$ & $+/-$ & $+/-$ \\
\hline Itakonic acid & $+/-$ & $+/-$ & $+/-$ & $+/-$ \\
\hline Glycyl-L-glutamic acid & $+/-$ & $+/-$ & $+/+$ & $+/-$ \\
\hline D-cellobiose & $+/+$ & $+/-$ & $+/-$ & $+/-$ \\
\hline Glucose-1-phosphate & $+/-$ & $-/-$ & $-/-$ & $-1-$ \\
\hline$\alpha$-ketobutyric acid & $-/-$ & $+/-$ & $+/-$ & $-/-$ \\
\hline Phenylethyl-amine & $+/-$ & $+/-$ & $+/-$ & $+/-$ \\
\hline$\alpha$-D-laktose & $-1+$ & $+/-$ & $-/-$ & $+/-$ \\
\hline D,L- $\alpha$-glycerol phosphate & $-/-$ & $+/-$ & $+/-$ & $+/-$ \\
\hline D-malic acid & $+/-$ & $+/-$ & $+/-$ & $+/-$ \\
\hline Putrescine & $+/-$ & $+/-$ & $+/-$ & $+/-$ \\
\hline Number of utilization C sources & $24 / 9$ & $29 / 3$ & $27 / 6$ & $25 / 7$ \\
\hline$\%$ of utilization substrates & $77 / 29$ & $94 / 10$ & $87 / 19$ & $81 / 23$ \\
\hline
\end{tabular}

We found statistically significant differences from the values of metabolic community differences only between individual hours of measurment using analysis of variance (LSD test, $\mathrm{P}<0.05$ ). Neither the amended fertilizers of experiment nor the day of incubation of samples had to CMD statistically significant effect. We 
recorded statistically significant differences (LSD test, $\mathrm{P}<0.05$ ) according to the statistical evaluation AMR between tretments of experiment, time of measurement and day of experiment (Table 5).

Table 5. Statistically significant differences between treatments, time of observation and day of experiment of community metabolic diversity (CMD) and average metabolic response (AMR) soil amended by fertilizers

\begin{tabular}{lcl}
\hline & CMD & AMR \\
\cline { 2 - 3 } Treatment & $12.19^{\mathrm{a}}$ & $0.42^{\mathrm{a}}$ \\
\hline T1 & $12.38^{\mathrm{a}}$ & $0.43^{\mathrm{ab}}$ \\
T2 & $12.56^{\mathrm{a}}$ & $0.46^{\mathrm{b}}$ \\
T3 & $12.63^{\mathrm{a}}$ & $0.53^{\mathrm{c}}$ \\
\hline Time of observation & & $3.50^{\mathrm{a}}$ \\
\hline $24 \mathrm{~h}$ & $0.06^{\mathrm{a}}$ & $9.13^{\mathrm{b}}$ \\
$48 \mathrm{~h}$ & $0.26^{\mathrm{b}}$ & $11.30^{\mathrm{c}}$ \\
$72 \mathrm{~h}$ & $0.39^{\mathrm{c}}$ & $13.13^{\mathrm{d}}$ \\
$96 \mathrm{~h}$ & $0.46^{\mathrm{d}}$ & $14.33^{\mathrm{e}}$ \\
$120 \mathrm{~h}$ & $0.54^{\mathrm{e}}$ & $15.00^{\mathrm{e}}$ \\
$144 \mathrm{~h}$ & $0.60^{\mathrm{f}}$ & $16.33^{\mathrm{f}}$ \\
$168 \mathrm{~h}$ & $0.66^{\mathrm{g}}$ & $16.79^{\mathrm{f}}$ \\
$192 \mathrm{~h}$ & $0.70^{\mathrm{h}}$ & \\
\hline Day of experiment & & $0.84^{\mathrm{a}}$ \\
\hline $1^{\text {st }}$ & $20.34^{\mathrm{a}}$ & $0.08^{\mathrm{b}}$ \\
\hline 105 & $4.53^{\mathrm{b}}$ & (h) \\
\hline
\end{tabular}

(Means followed by the same letter (s) within each column are not significantly different at $\mathrm{P} \leq 0.05$ )

\section{Conclusion}

The microbial carbon and physiological characterization of microbial community rised in treatment of soil amended with Azoter, biosludge and Azoter with biosludge in laboratory conditions, in the $1^{\text {st }}$ day of experiment. Biolog examinations showed that substrate richness and Average metabolic response were the highest in the treatment amended with Azoter with biosludge. Utilization of organic substrates with soil microbial community after application bio-fertilizers was the highest in treatment with Azoter. DGGE fingerprinting demonstrated that the distrubation patterns of most bands of $16 \mathrm{~S}$ rDNA and 18S rDNA increase in treatments with the addition of Azoter and Azoter with biosludge after 105 days compared to the $1^{\text {st }}$ day of incubation. The results from correlation graph of principal components analysis (PCA) confirmed differences in composition of community at the beginning and at the end of the experiment as well as differences between the treatments where biosludge was added separately and with biosludge, compared with the soil and soil treated with Azoter.

\section{Acknowledgements}

This work was supported by European Community under project „Building Research Centre AgroBioTech" No. 26220220180 and by the Ministry of Education by the Slovak Research Grant Agency from pro project No. VEGA 1/0476/13.

\section{References}

Anderson, I.C., Parkin, P.I., Campbell, C.D., 2008. DNA- and RNA-derived assessments of fungal community composition in soil amended with sewage sludge rich in cadmium, copper and zinc. Soil Biolgy and Biochemistry 40: 23582365.

Arthurson, V., 2008. Proper Sanitization of Sewage Sludge: a Critical Issue for a Sustainable Society. Applied and Environmental Microbiology 74: 5267-5275.

Brons, J.K., Van Elsas, J.D., 2008. Analysis of Bacterial Communities in Soil by Denaturing GradientGel Electrophoresis and Clone Libraries as Influenced by Different Reverse Primers. Applied and Environmental Microbiology 74: 2195-2107.

Cercioglu, M., Okur B., Deli S., Ongun, A.R., 2014. Changes in physical conditions of a course textured soil by addition of organic wastes. Eurasian Journal of Soil Science 3: 7-12.

Crecchio, C., Curci, M., Pizzigallo, M.D.R., Ricciuti, P., Ruggiero, P., 2004. Effects of municipal solid waste compost amendments on soil enzyme activities and bacterial genetic diversity. Soil Biolgy and Biochemistry 36: 15951605. 
Franzluebbers, A.J., Wilkinson, S.R., Stuedemann, J.A., 2004. Bermudagrass management in the Southern Piedmont, USA: IX. Trace elements in soil with broiler litter application. Journal of Environmental Quality 33: 778-784.

Garbeva, P., Van Veen, J.A., Van Elsas, J.D., 2004. Microbial diversity in soil: Selection of microbial populations by plant and soil type and implications for disease suppressiveness. Annual Review of Phytopathology 42: 243-270.

Garland, J.L., Mills, A.L., 1991. Classification and characterization of heterotrophic microbial communities on the basis of patterns of community-level sole-carbon-source utilization. Applied and Environmental Microbiology 57: 2351- 2359.

Ge, Y., Zhang, J.B., Zhang, L.M., Yang, M., He, J.Z., 2008. Long-term fertilization regimes affect bacterial community structure and diversity of an agricultural soil in northern China. Journal of Soils and Sediments 8: 43-50.

Gu, Y., Zhang, X., Tu, S., Lindström, K., 2009. Soil microbial biomass, crop yields, and bacterial community structure as affected by long-term fertilizer treatments under wheat-rice cropping. European Journal of Soil Biology 45: 239246.

Guanghua, W., Junjie, L., Xiaoning, Q., Jian, J., Yang, W., Xiaobing, L. 2008. Effects of fertilization on bacterial community structure and function in a black soil of Dehui region estimated by Biolog and PCR-DGGE methods. Acta Ecologica Sinica 28: 220-226.

Gutiérrez-rojas, I., Torres-geraldo, A.B., Moreno-Sarmiento, N., 2011. Optimising carbon and nitrogen sources for Azotobacter chroococcum growth. African Journal of Biotechnology 10: 2951-2958.

Cherif, H., Ayari, F., Ouzari, H., Marzorati, M., Brusetti, L., Jedidi, N., Hassen, A., Daffonchio, D., 2009, Effects of municipal solid waste compost, farmyard manure and chemical fertilizers on wheat growth, soil composition and soil bacterial characteristics under Tunisian arid climate. European Journal of Soil Biology 45: 138-145.

Chu, H., Lin, X., Fujii, T., Morimoto, S., Yagi, K., Hu, J., Zhang, J., 2007. Soil microbial biomass, dehydrogenase activity, bacterial community structure in response to long-term fertilizer management. Soil Biolgy and Biochemistry 39: 2971-2976.

Laboratory for Microbial Ecology. 2004. Department of Earth, Ecological and Environmental Sciences, University of Toledo. Community level physiological profiling (CLPP). Available at: http://www.eeescience.utoledo.edu/Faculty/Sigler/Von_Sigler/LEPR_Protocols_files/CLPP.pdf

Marschner, P.,Yang, C.H., Lieberei, R. Crowley, D.E., 2001. Soil and plant specific effects on bacterial community composition in the rhizosphere. Soil Biolgy and Biochemistry 33: 1437-1445.

Marschner, P., Kandeler, E., Marschner, B., 2003. Structure and function of the soil microbial community in a long-term fertilizer experiment. Soil Biolgy and Biochemistry 35: 453-461.

Odlare, M., Arthurson, V., Pell, M., Svensson, K., Nehrenheim, E., Abubaker, J., 2011. Land application of organic waste effects on the soil ecosystem. Applied Energy 88: 2210-2218.

Preston-Mafham, J., Boddy, L., Randerson, P.F., 2002. Analysis of microbial community functional diversity using solecarbon-source utilisation profiles - a critique. FEMS Microbiology Ecology 42: 1-14.

Vance E.D., Brookes P.C., Jenkinson D.S., 1987. An extraction method for measuring soil microbial biomass. Soil Biolgy and Biochemistry 19: 703-707.

Vainio, E.J., Hantula, J., 2000. Direct analysis of wood-inhabiting fungi using denaturing gradient gel electrophoresis of amplified ribosomal DNA. Mycological Research 104: 927-936.

Vessey, J.K., 2003. Plant growth promoting rhizobacteria as biofertilizers. Plant and Soil 255: 571-586.

Wu, S.C., Cao, Z.H., Li, Z.G., Cheung, K.C., Wong, M.H., 2005. Effects of biofertilizer containing N-fixer, P and k solubilizers and AM fungi on maize growth: a greenhouse trial. Geoderma 125, 155-166.

Wu, T., Chellemi, D.O., Graham, J.H., Martin, K.J., Rosskopf, E.N., 2008. Comparison of soil bacterial communities under diverse agricultural land management and crop production practices. Microbial Ecology 55: 293-310. 